\title{
La colaboración como base para la educación moderna (como lo ejemplifica la educación general primaria)
}

\author{
Collaboration as a foundation for modern education (as exemplified by primary \\ general education)
}

\author{
Natalya A. Nekhoroshikh ${ }^{1 \mathrm{a}}$ \\ Bunin Yelets State University, Yelets, Russia ${ }^{1}$ \\ Orcid ID: https://orcid.org/0000-0002-8222-1485 ${ }^{1}$
}

Recibido: 08 de setiembre de 2020

Aceptado: 14 de enero de 2021

\begin{abstract}
Resumen
El autor tiene como objetivo estudiar la implementación del análisis teórico de la cooperación como la base fundamental más fructífera de la educación para el logro de altos resultados, identificando las circunstancias subjetivas y objetivas de la influencia del nivel de desarrollo de habilidades de cooperación en el éxito de la enseñanza de estudiantes más jóvenes. El abordaje integral del estudio del problema fue el método principal que permitió considerar este tema en tres aspectos: desde el lado de los escolares de primaria, docentes y directores de primaria y directores de instituciones educativas. El autor identificó condiciones socio pedagógicas y psicológicas que aseguran un incremento en el desempeño de los estudiantes más jóvenes en el proceso educativo a partir de ideas de cooperación, así como factores que inhiben el desarrollo de su cooperación, lo que afecta negativamente el desempeño académico. Se ha comprobado empíricamente que la organización del proceso educativo en la escuela primaria a partir de las ideas de cooperación, cuando los estudiantes son sujetos de relaciones educativas, contribuye a su logro de mayores resultados de aprendizaje. La trascendencia de los resultados de la investigación obtenidos es demostrar las consecuencias positivas de construir el proceso educativo basado en la cooperación.
\end{abstract}

Palabras clave: Colaboración, educación general, escuela primaria, rendimiento académico.

\begin{abstract}
The author aims to study the implementation of the theoretical analysis of cooperation as the most fruitful fundamental basis of education for achieving high results, identifying the subjective and objective circumstances of the influence of the cooperation skills development level on the success of teaching younger students. An integrated approach to studying the problem was the leading method that made it possible to consider this issue in three aspects: from the side of primary schoolchildren, primary school teachers and principals, and head teachers of educational institutions. The author identified socio-pedagogical and psychological conditions that ensure an increase in the performance of younger students in the educational process based on ideas of cooperation, as well as factors that inhibit the development of their cooperation, which negatively affects academic performance. It has been proven empirically
\end{abstract}


that the organization of the educational process in primary school based on the ideas of cooperation, when students are the subject of educational relations, contributes to their achievement of higher learning outcomes. The significance of the research results obtained is to prove the positive consequences of building the educational process based on cooperation.

Keywords: collaboration, general education, primary school, academic performance.

\section{Introduction}

In the last decade, the global restructuring of the educational paradigm at the state level is taking place in Russia. These amendments are associated not only and not so much with the reorganization of the country's educational system in compliance with the world standards, but, first of all, with the rethinking of the fundamental basis for understanding the goals, mechanisms, and results of education. The Eurydice report presented the results of international research and suggested that "collaborative culture in school may positively affect the motivation of teachers, the effectiveness of their teaching, and their job satisfaction" (European Commission, 2015).

According to Aronson (1980); Vopel (1996); Kubiczek \& Rompała (2003), the relevance of the research is determined by the fact that the development of collaborative skills in younger schoolchildren contributes to their successful learning, building constructive interaction with other subjects of the educational process in achieving their goals of personal, social, and cognitive development, ensuring their social adaptation and adequate regulation of their behavior in interaction with people around them in various social situations (Makarenko, 1987; Baiborodova, 2012; Vitkovskaya, 2014; Kravtsov, 2017; Zuckerman, 2020).

The author assumed that the organization of the educational process in primary school based on the ideas of collaboration, when the younger student is the subject of educational relations, contributes to their achievement of higher learning outcomes. The purpose of the study is to carry out a theoretical analysis of collaboration as the most productive fundamental basis of education for achieving high results, identify subjective and objective circumstances of the influence of the level of collaborative skills development among junior schoolchildren on their success in learning. Research objectives include:

1) To analyze theoretically the scientific literature on the implementation of the educational process based on the ideas of collaboration in the history of global and Russian pedagogical experience;

2) To substantiate empirically the positive influences of building the collaboration-based educational process on high learning outcomes for junior schoolchildren;

3) To determine the subjective and objective conditions for the influence of the junior schoolchildren's collaborative skills development on their success in learning. 


\section{Literature review}

The results presented in numerous theoretical and scientific-methodological studies conducted both in Russia and abroad, largely characterize the collaboration regarding a certain age of children, in isolation from other age periods. This situation cannot but complicate the creation of a unified picture of understanding collaboration as a foundation of education, regardless of the learners' age.

The construction of a collaboration-based educational process for its subjects is not new for psychological and pedagogical science. Back in the $18^{\text {th }}$ century, two outstanding people, Bell and Lancaster, began a new round in the development of education, independently of each other developing a system of mutual learning, which was based on the idea of interaction between a teacher and senior students, and then senior students with junior students. Thus, a didactic process was constructed, in which the goal of learning could be achieved only through the collaboration of all its participants. In the history of education development, this system entered under the name "Bell-Lancaster System".

At the present stage, the majority of Russian and foreign scholars recognize the collaboration-based organization as the most effective option for obtaining a high-quality education. However, the vector of the application of collaboration ideas in the pedagogical process has changed: first, it is necessary to prepare learners for collaboration so that they could successfully learn and develop. For this purpose, it is necessary to form their competencies that contribute to building constructive communication and collaboration with all participants in educational relations (Aini et al., 2020; Hamoud \& Humadi, 2019).

An American teacher and psychologist Aronson (1980) concluded on the basis of his research that an unfriendly atmosphere in the classroom and a lack of respect for each other in the children's teams negatively affect the learning process and outcomes, and later other spheres of the children's life, hampering their development. A German psychologist Vopel (1996) agreed with Aronson (1980) in his position regarding the influence of the ability to cooperate with other people on their success, in particular, in obtaining an education, which justified the need to develop this ability in a person from an early age.

The practical experience of Polish researchers Kubiczek \& Rompała (2003) confirms the assumption that the atmosphere of collaboration and mutual assistance in the teaching staff of the school has a beneficial impact on the efficiency of the educational process and the achievement of gains in performance not only in teaching but also in upbringing. In addition, students, following the example of teachers, model collaboration situations in their behavior and communication, which leads to stimulation of the child's development process both in the educational institution and outside it. 
In the Russian pedagogy, Makarenko (1987) was the first to develop and apply in practice the most effective solution to the problem of organizing the pedagogical process based on the collaboration ideas. His theory of collective education set a new direction for pedagogical activity. Makarenko (1987) built the technology of educating a child's personality in a team through the mutual influence of members of the children's community among themselves and teachers, relying on collaboration, feeling of shelter, support, mutual assistance, but at the same time, on the responsibility of each for oneself and for others.

Later, in the second half of the $20^{\text {th }}$ century, the ideas of "collaborative pedagogy" were very popular in Russian education. Against the background of the traditional classical provisions of the classroom-lesson teaching system, which at that time were used in school without any alternatives, the ideas of collaborative pedagogy about the essence and organization of the educational process without coercion seemed innovative and revolutionary. It was not represented by a monolithic theory. Collaborative pedagogy united the ideas of several innovative educators of the time, who had a single fundamental image - a collaboration between all subjects of educational relations. First, these were the provisions and technologies of such scholars as Soloveichik (1986), Amonashvili (1983), Shatalov (1980), Lysenkova et al. (1985). In collaborative pedagogy, the subject role in the process of teaching and upbringing was assigned not only to the teacher but to the learners, as well. At the same time, the interrelations between children and teachers were built based on a humane and personal approach.

In domestic psychological and pedagogical studies, the problem of collaboration development is widely reflected in its various aspects. Vygotsky (1984), Galperin (1985), Leontief (1947), Rubinstein (1997), Elkonin (1930). singled out this problem as an independent one and were engaged in its further development; the problem of a child's collaboration with other children was studied by Derevyanko (1983), Lisina (1982), Mudrik (1997), Ruzskaya (2007); the development of collaboration in joint activities was considered by Kravtsov (2017), Markova (1975), Rean (2013); the peculiarities of teacher-junior schoolchild collaboration were studied by Bozhovich (1979), Lyublinskaya (1977), Laudis (1998), Soloveichik (1986), Zuckerman (2010); the techniques and methods for organizing educational collaboration are described in the works of Aidarova (1988), Liimets (1982), Matis (1977), Rubtsov (1996); formation of collaborative skills is revealed in the studies by Aidarova (1988), Baiborodova (2012), Bodalev (2008), Vitkovskaya (2014), Vygotsky (1984), Krushelnitskaya \& Tretiakova (2004), and Zuckerman (2020). At the present stage of domestic science development, there is no single concept of collaboration. Each of the authors defines it according to their position.

In the Concept for the Development of Education in the Russian Federation for 20162020, collaboration is interpreted as the idea of joint developmental activities of adults and children, reinforced by mutual understanding, penetration into the spiritual world of each other, 
and joint analysis of the progress and results of these activities" (Government Decree, 2014). The educational collaboration fits into a new model of education, a humanistic and learnercentered approach. The current formulation of the problem of developing collaborative skills in schoolchildren during the learning process corresponds to the modernization of Russian education, most of which meets the needs of people of our time regarding the increase in the human factor.

In modern psychological and pedagogical science (Konnikova, 1957; Mudrik, 1997; Feldstein, 2008; Zuckerman, 2020; Yadov, 2007) collaboration between the subjects of educational relations is considered as a specific form of educational interaction between children themselves, between children and the teacher, in which the children's personal initiative is maximally revealed, a mutual exchange takes place, and a positive reaction to the individuality of the participants in the interaction arises.

The characteristics of collaboration between participants in the pedagogical process, identified in modern psychological and pedagogical publications (Zhuravlev, 2005; Diachenko, 1997; Kandybovich, 2018; Mudrik, 1997; Umansky, 1980; Zuckerman, 2020; Shevandrin, 1995), can be summarized as follows:

- Spatial and temporal presence;

- Common goal and common motivation;

- Purposefulness and controllability of activities;

- Differentiation of the process of activity between the participants;

- Consistency to obtain a single end product;

- The existence of favorable interpersonal relationships in the process of joint activities.

Zimnyaya (2010) developed and substantiated a multifunctional structure of pedagogical interaction in the collaboration-based educational process consisting of four groups: 1) teacher-student (students), 2) student-student in pairs (dyads) and triplets (triads), 3) group-wide interaction of students in the entire educational team, for example, in the language group, in the whole class, and 4) teacher - teaching staff. Zuckerman (2010) added one more important genetic derivative from all other lines - the student's collaboration "with oneself".

Zuckerman \& Elizarova (2020) also identified the following positive aspects of joint educational activities, stating that collaboration assists in mastering the studied material; increases cognitive functions and creativity in children; minimizes the time spent on developing knowledge and skills; promotes a positive emotional state of students; organizes class cohesion; helps in acquiring social skills - responsibility, self-control, totalitarianism; organizes the division of children into groups, proceeding from mutual sympathy; and enriches the importance of the teacher's upbringing work. 
The listed characteristics of collaboration provide an opportunity to consider the influence of the level of collaborative skills development in junior schoolchildren on their success in learning, which presupposes constructive interaction and collaboration between the subjects of the educational process, the activation of the personal potential in both teachers and students.

However, the vast majority of studies on the problem of the collaboration of participants in the educational process were carried out on the example of adolescence, while collaboration among primary school children is understudied. According to the prevailing position in the psychological and pedagogical sciences, the sensitivity of this age is important for the formation and development of both moral and socially significant personality traits and behavioral norms that determine the vector of children's interactions during communication (Bahtiar \& Sartono, 2020).

\section{Methodology}

The author chose a diagnostic toolkit for the research, which included: the Carpet technique by Ovcharova (2007); the Mittens technique by Zuckerman (2010); the Incomplete Fairy Tale technique by Venger (1989); the Collaboration Level in Primary Schoolchildren' Team test by Elkonin (1930); conversations, polls; analysis of school documents; expert assessment of the junior students' ability to collaborate; and expert assessment of the style of pedagogical activity of primary school teachers.

The research was conducted in municipal budgetary educational institutions of the urban district of Yelets and the Yelets municipal district of the Lipetsk Region of the Russian Federation in 2019-2020. The research covered 315 primary schoolchildren studying in grades 3 and 4, 11 primary school teachers, and 22 representatives of the administration of the educational institutions (principals and directors of studies of secondary schools). The empirical research was conducted in three directions using several research methods:

- With primary schoolchildren (315 persons) - observation, conversations, the Collaboration Level in Primary Schoolchildren' Team test by Elkonin (1930) the Carpet technique by Ovcharova (2007); the Mittens technique by Zuckerman (2010); the Incomplete Fairy Tale technique by Venger (1989);

-With primary school teachers (11 persons) - conversations, inquiries, analysis of school Documents, expert assessment of the ability to cooperate in primary schoolchildren;

- With principals and directors of studies of the educational institutions (22 persons) interviews, inquiries, analysis of school documents, expert assessment of the style of primary school teachers' pedagogical activity. 
By employing the above methods of working with principals and directors of studies, the author was able to select for participation in our study only those teachers who organize the educational process in their classes, relying on collaboration ideas. The use of several research methods when working with the representatives of the administration of secondary schools enabled to exclude subjectivity in assessing the style of pedagogical activity of primary school teachers and the probability for teachers who adhere to other styles of pedagogical activity to get involved in the experimental work.

\section{Results}

In the course of this research, it was found that a positive effect on junior schoolchildren' success in learning is achieved by the level of collaborative skills development with regard to certain subjective and objective conditions, the norms and values of the cultural and educational environment, the teacher's style of work and communication, the socio-psychological type of personality of the teacher and schoolchildren, and the structure of social relations in the environment of the child. The socio-pedagogical and psychological conditions that ensure the growth of primary schoolchildren' academic performance in the collaboration-based educational process include:

- The idea of collaboration is the foundation of pedagogical interaction, according to the Federal State Educational Standard of the Primary General Education of the Russian Federation (RF FSES PGE) and the demands of the contemporary society; this idea is considered as the interaction of subjects, limited by a single goal, the skills of mutual understanding, interaction and the coincidence of interests to achieve the final result;

- High state requirements for the level of the learners' general education, which are declared in the RF FSES PGE, determine the need to account for the component of the educational process continuity and an integrated approach of various methods and techniques in the formation of communicative competence in all its diversity, starting from a preschool age;

- In addition to the realization of a cognitive, creative goal, collaboration in the educational process involves achieving a psychological and social target, that is, it contributes to the development and socialization of the primary schoolchildren's personality;

- Newly formed structures of the primary school age, improvement of the work of mental processes, expansion of the range of situations that contribute to the process of a child's socialization act as sensitive factors in mastering the skills of collaboration with subjects of educational relations for successful learning; 
- - The use of group forms (educational dialogue, paired and team work, games, etc.) for the development of collaborative skills among primary schoolchildren is actualized from the children's general need for an active exchange of decisions, which maximally contributes to their active participation in the educational process, including collaboration;

- While implementing the collaborative-based pedagogical process, the primary school teacher should pay special attention to the qualitative aspect of the forms of interpersonal interaction since children of primary school age imitate the behavior of significant adults, and the teacher is primarily related in this age period;

- Collaborative skills help learners evaluate certain events from different points of view, acquire an interest in continuing education and independence, overcome stress and control the emotional sphere;

- Group work provides an opportunity for schoolchildren to feel connected with each other, to realize their significance in a team, learn to establish interpersonal contacts, formulate their thoughts, and adequately respond to criticism.

In the framework of this empirical study, 22 principals and directors of studies (for primary education, if there were any in the staff list of the school) of municipal budgetary educational institutions of the urban district of Yelets and Yelets municipal district of the Lipetsk Region, Russia, were involved as experts for assessing the style of pedagogical activity of primary school teachers. To determine the consistency of the expert group and the significance of the data obtained, the calculation of the concordance coefficient was used:

$$
W=\frac{12 S}{m^{2}\left(n^{3}-n\right)}
$$

Where $m$ is the number of experts, $S$ is the sum of squared deviations of the sums of ranks received by each teacher $(n)$ from the average sum of ranks. The obtained value $W=0.84$ states the consonance of experts and the reliability of the results obtained.

Diagnostic tools when working in two other areas of this empirical research allowed for assessing objectively the level of collaboration development between primary schoolchildren, and between learners and teachers and to state the learning outcomes of each schoolchildren individually.

The expert assessment of the primary schoolchildren' ability to cooperate was carried out with primary school teachers (11 persons), with whose students an empirical study was conducted. The results obtained in the course of this research were processed according to a similar formula above, where $m$ is the number of experts; $S$ is the sum of squared deviations of 
the sums of ranks received by each teacher $(n)$ from the average sum of ranks. The resulting value $W=0.80$ indicates the experts' balanced work and the reliability of the results.

Quantitative results of research methods (observation, conversations, the Collaboration level in primary schoolchildren' team test by Elkonin (1930), the Carpet technique by Ovcharova (2007); the Mittens technique by Zuckerman (2010); the Incomplete Fairy Tale technique by Venger (1989), conducted with schoolchildren (315 persons) in classes, which are taught by the teachers who took part in our study, suggest that the majority of children have developed collaborative skills at a sufficiently high level that allows them to learn successfully (Figure 1). Only schoolchildren of the third and fourth grades of the initial stage of general education were selected purposefully for participation in the research work since by this time the periods of children's adaptation to school education and the formation of a children's team in classes will have been completed.

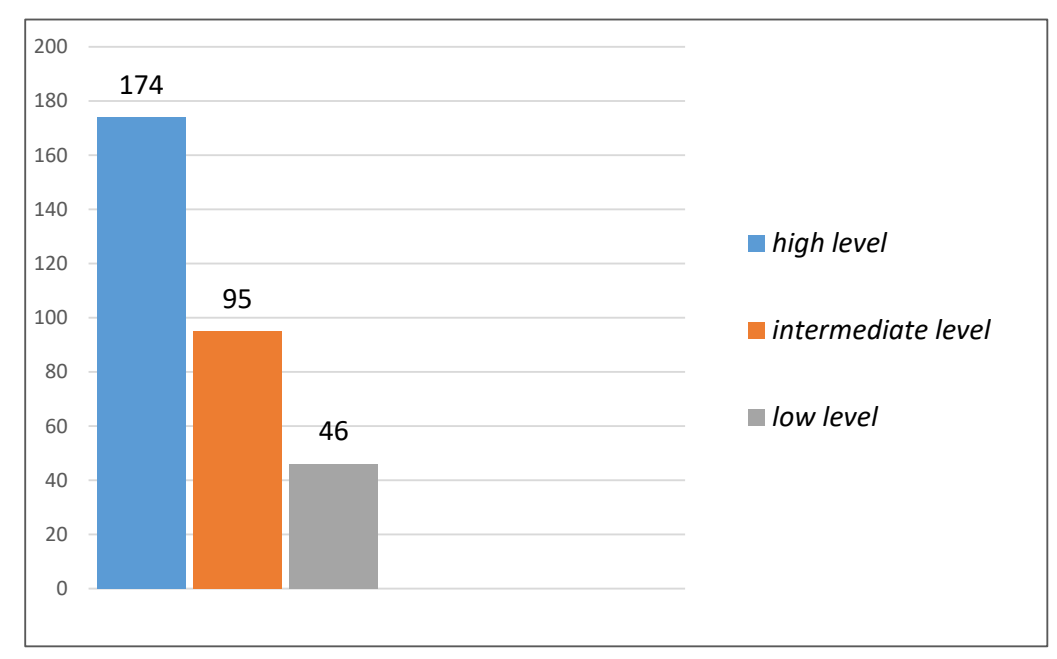

Figure 1. Distribution of primary schoolchildren by levels of collaborative skills (regarding the number of persons)

Based on the synthesis of the obtained quantitative and qualitative data for all diagnostic techniques, the author identified three levels of collaborative skills in primary schoolchildren (Figure 2). 


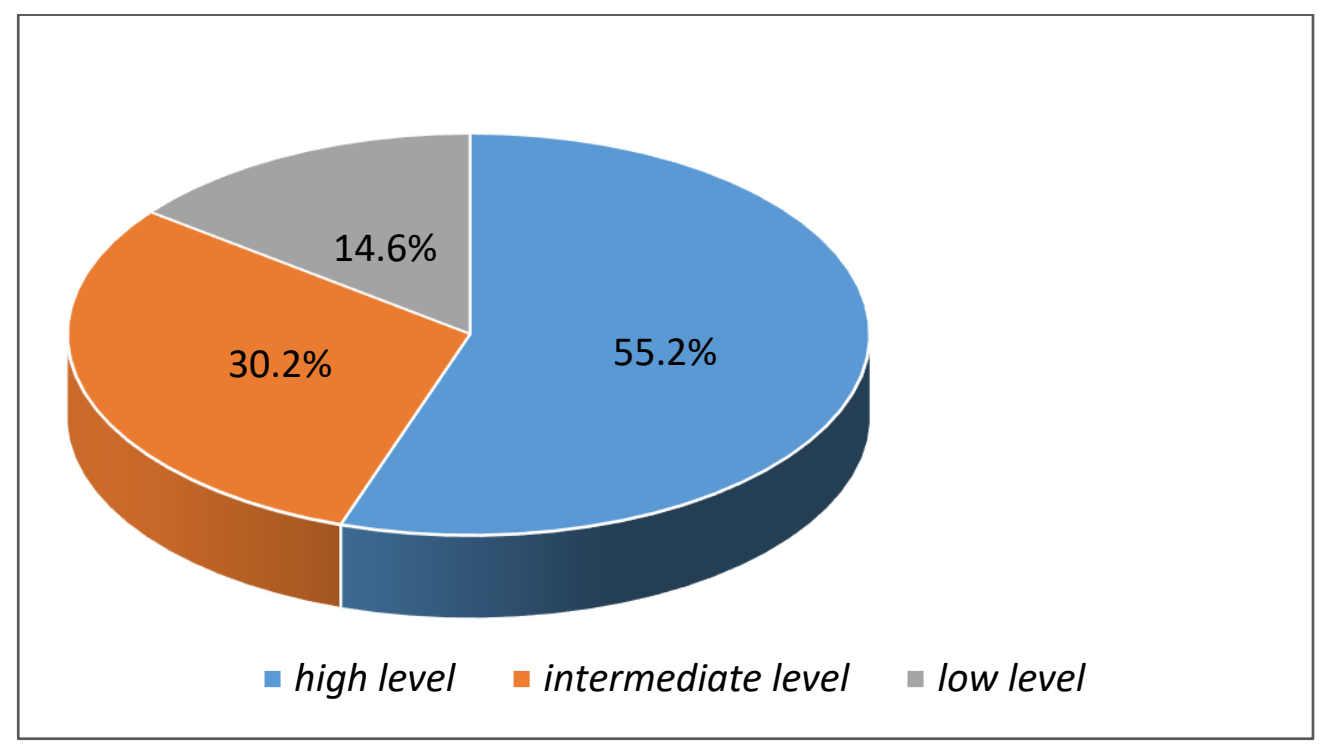

Figure 2. Distribution of primary schoolchildren by levels of collaborative skills (in \%)

A high level: children actively discuss various issues, they can agree and come to a common opinion both with classmates and with a teacher, willingly listen to the opinion of others, can work independently and in micro-groups, they become leaders who coordinate and control the actions of other children.

An intermediate level: collaboration is situational (children notice the partner's actions only in each specific situation), children are not able to predict the partner's actions and develop a common way to solve the problem, they can listen and negotiate, but without emotion, sometimes they succeed in reaching a certain agreement about further joint actions to achieve a common goal.

A low level: children do not see the partner's actions, they can neither anticipate partners' actions, nor search for common ways to solve the problem, they do not communicate with each other, there is no partner dialogue, empathy for each other; children have low selfesteem and a negative attitude towards other children, or high self-esteem, but at the same time a bad attitude towards others.

The analysis of the school documents and the documentation accompanying work in the classroom allows for asserting that the level of primary schoolchildren' collaborative skills development and their learning success are correlated (Figure 3). 


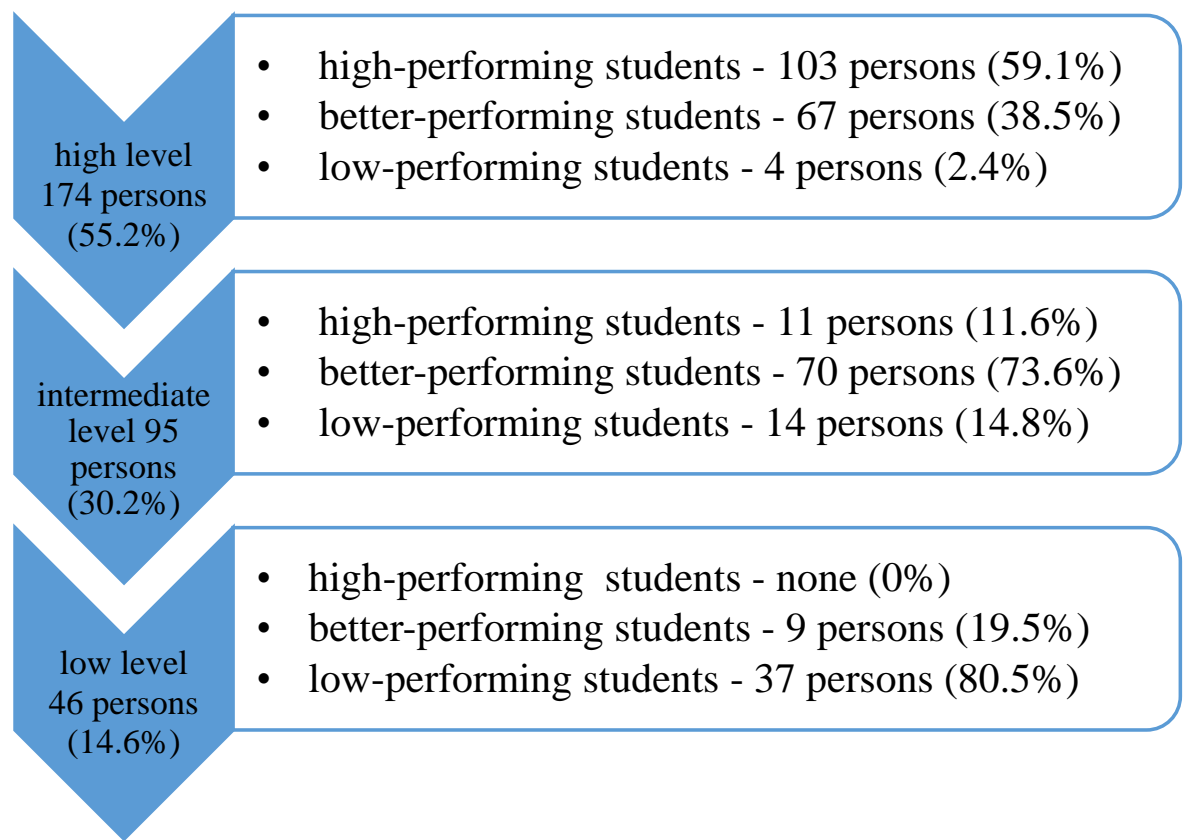

Figure 3. Correlation of the level of primary schoolchildren' collaborative skills development and their general academic performance in the main disciplines (in quantitative proportions and percentage)

\section{Discussion}

A theoretical analysis of the problem of collaboration as the most productive fundamental basis of education for achieving high results showed the effectiveness of this assumption, subject to some subjective and objective circumstances for the organization of the educational environment and prevention of negative factors, which were mentioned above in the Research Results section.

When conducting a study with representatives of administrations of secondary schools concerning the selection of primary school teachers, whose work is based on the ideas of collaboration, it was revealed that about only half (57\%) of teachers of this profile build the educational process in this way.

The creation and maintenance of collaborative relationships in a class team is the main pedagogical condition for the formation of a personality which is ready for dialogue and mutual understanding, at the same time capable of expressing own individuality and achieving high success in education. Nevertheless, the pedagogical process is a specially modeled system, the participants of which are endowed with certain powers. This duality raises the problem of purposefully creating the conditions for the development of collaborative skills and situations for their implementation. The collaboration-based system includes the following components:

- Diagnostics of psychological compatibility of learners in interaction;

- Creation of social, psychological, and pedagogical conditions for work in collaboration; 
- Design of pedagogical and cognitive activities through the implementation of training in collaboration.

The results of similar studies are presented in the scientific community. The most famous are the experiments conducted by a group of scientists led by Lewin (2006), Maslova (1969) and Bodalev (1995). As a result of the work of a group of like-minded people consisting of Lippit, White and Lewin (2006), three types of leadership (authoritarian, conniving, democratic) were identified, which are now better known in science as "leadership styles" and their different influence on the behavior of the group and development of personality traits of group members. They concluded that the most humane way of influencing human development is precisely the democratic style of leadership. However, they do not idealize him. The authors cite the pros and cons of applying each of the leadership styles in relation to specific conditions and an object, and advocate a reasonable combination of them depending on the current situation.

Maslova (1969) studied the influence of different styles of teacher leadership on the attitude of students towards learning and school. She concludes that only a democratic style of interaction between a teacher and students has a positive effect on the formation of students' motivation to learn and the desire to attend an educational institution. She found that children are not so much afraid of difficulties in the learning process as misunderstanding or even rejection on the part of teachers.

A study by Bodalev (1995) aimed at establishing the relationship between the styles of pedagogical communication and the teacher's assessment of the personality of his pupils. The results showed that teachers who adhere to the democratic style in interaction with students objectively perceive the personality of schoolchildren.

However, the object of scientific interest in the studies reviewed was somewhat different: the styles of pedagogical communication. However, at the same time, the idea of cooperation lies at the heart of the democratic style of pedagogical communication. Therefore, the results obtained in the course of these studies indirectly, but confirm the theoretical and empirical conclusions of the author. Researches similar to ours, the purpose of which would be to study cooperation, as the most effective fundamental basis of education for achieving high results, has not been conducted before.

Considering the specifics of the implementation of the educational process at different levels, depending on the age characteristics of students, in our study we limited ourselves only to primary general education. Since it is at this stage that the foundations of the "ability to learn" are laid in schoolchildren - the necessary knowledge and skills are formed to master various ways of obtaining education, the volitional qualities of the individual are brought up and 
developed, which contribute to an increase in motivation for learning, fundamental scientific concepts and initial knowledge that make up provisions of modern sciences. Collaboration as a fundamental basis of education allows you to achieve high results in solving assigned tasks most effectively. All this will form the foundation for successful education and development of the student's personality.

\section{Conclusion}

Summing up the results of our research, the author can summarize that the use of cooperation - the organization of group interaction in the education and upbringing of primary schoolchildren is reasonable and timely, which significantly and effectively improves the quality of modern education within the current educational standards of the new generation.

The positive consequences of building the educational process based on ideas of cooperation are: creating a sense of significance and involvement in the common cause of each subject of educational relations; the formation of universal educational actions in the process of group work; active discussion of the problems that have arisen without fear; fostering initiative and activity in achieving the goals of education; motivation for success in learning; development of mutual responsibility of all members of the class team.

\section{Acknowledgements}

The author expresses gratitude to the teaching staff and the learners of the municipal budgetary educational institutions of the urban district of Yelets and the Yelets municipal district of the Lipetsk Region of the Russian Federation, who acted as the base for the experimental work, for the opportunity to perform the research.

\section{References}

Aidarova, L. I. and Lvov, M. R. (1988). Creativity in teaching and upbringing - a strategy for building modern education, Psychology Issues, 4, 181-182. http://www.persev.ru/bibliography/tvorchestvo-v-obuchenii-i-vospitanii-strategiyapostroeniya-sovremennogo-obrazovaniya

Aini, M., Narulita, E. and Indrawati. (2020). Enhancing Creative Thinking and Collaboration Skills through ILC3 Learning Model: A Case Study. Journal of Southwest Jiaotong University, 55(4). http://jsju.org/index.php/journal/article/view/704

Amonashvili, Sh. A. (1983). Hello kids! A guide for the teacher. Moscow, Russia: Prosveshcheniye.

Arinushkina, A. and Dovbysh, S. (2019). Public and Professional Discussion on the Results of the Updated Content of Subject Education: Approaches in Primary General and Basic General Education. Journal of History Culture and Art Research, 8(1), 13-20. doi: http://kutaksam.karabuk.edu.tr/index.php/ilk/article/view/1943

Aronson, E. (1980). The social animal. San Francisco, USA: W. H. Freeman. 
Bahtiar, R. S. and Sartono E. K. E. (2020). The Role of Sociology in Development Primary School Education in Indonesia. Journal of Hunan University Natural Sciences, 47(11), 58-66. http://jonuns.com/index.php/journal/article/view/470

Baiborodova, L. V., Kirichenko, E. B., Paladiev, S. L. and Kharisova, I. G. (2012). Technologies of pedagogical activity. Organization of activities. Part 2. Yaroslavl: State Pedagogical University Press.

Bodalev, A. A. (1995). Personality and Communication: Selected Works. Moscow, Russia: International Teacher's Academy.

Bodalev, A. A. (2008). Psychology of mass communication. Moscow, Russia: Gardariki.

Bozhovich, L. I. and Slavina, L. S. (1979). The mental development of schoolchildren and their upbringing. Moscow, Russia: Znanie.

Derevyanko, R. I. (1983). Peculiarities of the preschool children' motives of communication with adults and peers (Unpublished dissertation for the degree of candidate of psychological sciences). Institute of General and Pedagogical Psychology.

Diachenko, O. M. (1997). The problem of individual differences in the intellectual development of a child. Psychology Issues, 4, 138-146.

Elkonin, D. B. (1930). The doctrine of behavior reflexes. Moscow, Russia: State Publishers.

Erikson, E. (1995). Childhood and society. London, England: Vintage Books.

European Commission/EACEA/Eurydice. (2015). The Teaching Profession in Europe: Practices, Perceptions, and Policies. Eurydice Report. Luxembourg: Publications Office of the European Union. https://www.anefore.lu/wpcontent/uploads/2015/09/EURYDICE-THE-TEACHING-PROFESSION.pdf

Feldstein, D. I. (2008). Man in the contemporary world: trends and potential development opportunities. Moscow, Russia: Moscow Psychological and Social Institute Press: NPO Modek.

Galperin, P. Ya. (1985). Methods of teaching and mental development of the child. Moscow, Russia: Moscow University Press.

Hamoud, A. K. and Humadi, A. M. (2019). Students' Success Prediction Model Based on Artificial Neural Networks (ANN) and a Combination of Feature Selection Methods. Journal of Southwest Jiaotong University, 54(3). doi: https://doi.org/10.35741/issn.0258-2724.54.3.25

Kandybovich, S. L. (2018). Strategies of psychological safety of a person in conditions of uncertainty. Human Capital, 8(116): 63-75. DOI: 10.25629/HC.2018.08.06

Konnikova, T. E. (1957). Organization of students' team at school: Generalization of the experience of school No. 210 in Leningrad. Moscow, Russia: Publishing house of the Academy of Pedagogical Sciences of the RSFSR.

Kravtsov, G. G. and Kravtsova, E. E. (2017). Psychology of the game: a cultural-historical approach. Moscow, Russia: Lev.

Krushelnitskaya, O. I. and Tretiakova, O. N. (2004). All Together. Program for teaching younger students to interact and collaborate. Moscow, Russia: Sphere.

Kubiczek, B. and Rompała, A. (2003). Doskonalenie szkoły poprzez uczenie się współpracy w radzie pedagogicznej. Szkoła jako uczaca się organizacja. Szansa dla ambitnych. Chorzów, Poland: Wydawnictwo Mentor. 
Laudis, V. Ya. (1998). A new paradigm of educational psychology and the practice of innovative education. Bulletin of Moscow University. Series 14. Psychology, 2, 88-97. https://www.gumer.info/bibliotek_Buks/Pedagog/hrist2/01.php

Leontief, A. N. (1947). Psychological issues of the consciousness of teaching. Transactions of the Academy of Pedagogical Sciences of the RSFSR, 7. https://www.marxists.org/russkij/leontiev/1975/dyeatyelnost/psychology-voprosy.htm

Lewin, K., Lippitt, R. and White, R. (2006). Experimental studies in the social climates of groups National Film Preservation Foundation (U.S.); Iowa Child Welfare Research Station. California, USA: Film Technology Company, Inc.

Liimets, H. I. (1982). How the learning process brings up. Moscow, Russia: Znanie.

Lisina, M. I. (1982). Development of children's cognitive activity in the course of communication with adults and peers. Psychology Issues, 4, 18-35.

Lysenkova, S. N. (1985). When it is easy to learn: From the experience of a primary school teacher at Moscow, school No. 587. Moscow, Russia: Pedagogy.

Lyublinskaya, A. A. (1977). For the teacher about the psychology of a younger student. Moscow, Russia: Prosveshcheniye.

Makarenko, A. S. (1987). Collected works in four volumes. Moscow, Russia: Pravda.

Markova, A. K. (1975). The psychology of teaching adolescents. Moscow, Russia: Znanie.

Maslova, N. F. (1969). Study of the role of small groups in an organized group of adolescents. Abstract of a thesis for the Candidate of Sciences (Pedagogy) (Unpublished dissertation for the degree of candidate of pedagogical sciences). Herzen State Pedagogy University.

Matis, T. A. (1977). Psychological conditions for the formation of joint educational activity of schoolchildren (PhD Thesis in Psychological Sciences). APN USSR. Research Institute of General and Educational Psychology.

Ministry of Education and Science of Russia. (2009). Order No. 373 as of Oct 06, 2009 (as amended on Dec 31, 2015) "On the approval and implementation of the Federal State Educational Standard for Primary General Education" (Registered in the Ministry of Justice of Russia on December 22, 2009, No. 15785). http://www.consultant.ru/document/cons_doc_LAW_96801/

Mudrik, A. V. (1997). Socialization and education. Moscow, Russia: September.

Nikitchuk, E. V. (2015). Teaching younger students in collaboration. January Pedagogical Readings, 1, 150-152.

Ovcharova, R. V. (2007). Reference book of the social educator. Moscow, Russia: Sphera.

Rean, A. A. (2013). Psychology of Personality. St. Petersburg, Russia: Peter.

Resolution of the Government of the Russian Federation No. 2765-r dated December 29, 2014 "On Approval of the Concept of the Federal Target Program for the Development of Education for 2016-2020”. http://static.government.ru/media/files/mlorxfXbbCk.pdf

Rubinstein, S. L. (1997). The principle of creative amateur performance. In Rubinstein S.L. Selected philosophical and psychological works. Fundamentals of Ontology, Logic and Psychology. http://voppsy.ru/issues/1986/864/864101.htm

Rubtsov, V. V. (1996). Atividade coletiva e de conceitos teyricos Fisica De por escolares. In Garnier, C., Bednarz, N.; Ulanovskaya, I. (Org.). Apys Vygotsky e Piaget: perspectiva social e construtivista. Escolas russa e ocidental Trad. Eunice Gruman. Porto Alegre: Artes Medicas. 
Ruzskaya, A. G. (2007). Development of speech. Games and activities with young children of 1-3 years. Moscow: Mosaika-Synthesis.

Shatalov, V. F. (1980). Pedagogical prose. From the experience of schools in Donetsk. Moscow: Pedagogy.

Shevandrin, N. I. (1995). Social psychology in education. Moscow: Vlados.

Soloveichik, S. L. (1986). Eternal Joy: Essays on Life and School. Moscow: Pedagogy.

Umansky, L. I. (1980). Psychology of organizational activity of schoolchildren. Moscow: Prosveshcheniye.

Venger, L. A., Diachenko, O. M., Govorova, R. I. and Tsekhanskaya, L. I. (1989). Games and exercises for the development of mental abilities in preschool children. Moscow, Russia: Prosveshcheniye.

Vitkovskaya, I. M. (2014). Technology of a collective way of teaching in a modern lesson at primary school. Siberian Teacher. Scientific and Methodical Journal, 2, 90-92. https://cyberleninka.ru/article/n/tehnologiya-obucheniya-v-sotrudnichestve-kaksredstvo-formirovaniya-universalnyh-uchebnyh-deystviy-mladshih-shkolnikov/viewer

Vopel, K. W. (1996). Kinder können kooperieren. Interaktionsspiele für die Grundschule. Lower Saxony, Germany: Iskopress Verlag.

Vygotsky, L. S. (1984). Pedology of a teenager. Selected Writings in six volumes. Vol. 4 (19291930). Moscow, Russia: Pedagogika.

Yadov, V. A. (2007). Sociological research strategy. Description, explanation, understanding of social reality. Moscow, Russia: Omega-L.

Zhuravlev, A. L. (2005). Psychology of joint activities. Moscow, Russia: RAS, Institute of Psychology Press.

Zimnyaya, I. A. (2010). Educational psychology: a textbook for students of higher educational institutions majoring in pedagogy and psychology. Moscow, Russia: Moscow Psychological and Social Institute Press; Voronezh: MODEK.

Zuckerman, G.A. (2010). How younger students learn to learn. Riga, Latvia: Pedagogical Center "Experiment".

Zuckerman, G.A. and Elizarova, N.A. (2020). Training learning collaboration. Psychology Issues, 4, 63-67. 